\title{
薬学教育における「ジェネリック医薬品実習」の実施とその効果
}

\author{
冨重恵利紗 ${ }^{1,2}$, 河内明夫 ${ }^{1,2}$, 平島智晃 ${ }^{2}$, 園田純一郎 ${ }^{1,2}$, 鳴海恵子 ${ }^{2}$, 本屋敏郎 ${ }^{* 1,2}$ \\ 九州保健福祉大学大学院医療薬学研究科 ${ }^{1}$, 九州保健福祉大学薬学部臨床薬学第一講座 ${ }^{2}$
}

\section{Training Program on Generic Drugs at a Pharmacy School and its Effects}

\author{
Erisa Tomishige ${ }^{1,2}$, Akio Kawachi ${ }^{1,2}$, Tomoaki Hirashima ${ }^{2}$, \\ Junichiro Sonoda ${ }^{1,2}$, Keiko Narumi ${ }^{2}$ and Toshiro Motoya ${ }^{* 1,2}$ \\ Graduate School of Clinical Pharmacy, Kyushu University of Health \& Welfare ${ }^{1}$, \\ First Department of Clinical Pharmacy, School of Pharmaceutical Sciences, Kyushu University of Health \& Welfare ${ }^{2}$ \\ $\left[\begin{array}{l}\text { Received May 29, } 2013 \\ \text { Accepted August 25, } 2013\end{array}\right]$
}

We conducted a training program at a pharmacy school to enhance students' understanding of the characteristics and roles of generic drugs. The program reviewed the quality (4 evaluation items), formulation properties, information delivery systems, drug supply systems (4 evaluation items), and patient's copayment for four types of formulations, each with brand-name and generic versions. This study evaluated the students' cognitive changes in regard to generic drugs and analyzed factors influencing these changes as well as the students' satisfaction with and opinions about the usefulness of the training. A questionnaire was distributed to 158 students who participated in the program in 2011, and 151 fully completed questionnaires were analyzed using regression analysis. Results indicate that the training program enhanced the students' interest in generic drugs. Of the evaluation items mentioned above, bioequivalence, name and appearance, drug adjuvant, formulation properties, and listing in the Japanese version of the Orange Book were positively correlated with understanding of generic drugs by using regression analysis. These findings suggest that the program was useful in increasing the students' understanding of the characteristics and roles of generic drugs. This was also considered to lead to a better ability to choose the appropriate drugs based on patients' needs and usability.

Key words — generic drugs, training program, pharmacy students, patients' needs

\section{緒言}

ジェネリック医薬品（GE）は, 先発医薬品（先 発品）の特許終了後に生物学的に同等であるとし て製造販売が承認されるもので, 先発品に比して 開発期間が短く，薬価も低く設定される，GEの 使用促進を図るために, 政府は GEへの重点強化 策として処方せん様式の変更や診療報酬・調剂報 酬の改定を打ち出し, 日本ジェネリック製薬協会 や GEメーカーは「信頼性向上プロジェクト（平 成 19 年 8 月)」を発足させ, 安定供給（納品まで の時間短縮や在庫の確保), 品質確保 (品質試験
の実施等)，情報提供体制の整備（ジェネリック 医薬品情報提供システムの構築等）および広報啓 発活動の強化等に取り組んできた（平成 24 年 8 月 29 日, http://www.jga.gr.jp/pdf/AP_Report_2012_ 08_29.pdf). また, 医療保険財政改善に向けた具 体的政策の 1 つとして, 今後行うべき取組みを厚 生労働省は「後発医薬品の安心使用促進アクショ ンプログラム」にまとめている (平成 19 年 10 月 15日, http://www.mhlw.go.jp/bunya/iryou/kouhatuiyaku/dl/17.pdf). 一方, 6 年制薬学教育の根幹と なる薬学教育モデル・コアカリキュラムおよび実 務実習モデル・コアカリキュラム（「薬学教育モ

\footnotetext{
* 宮崎県延岡市吉野町1714-1
} 
デル・コアカリキュラム」Excel 版, 2008 年 3 月, http://www.pharm.or.jp/kyoiku/modelcore curriculum.html）においては, 医薬品開発と生産 の実際を理解するための「GEの役割について概 説できる」以外に GEに関する到達目標がないの が現状である。

後発医薬品の使用状況調査結果概要（平成 23 年 10 月 21 日, http://www.mhlw.go.jp/bunya/iryou/ kouhatu-iyaku/dl/111205-01.pdf）によると，「後発 医薬品の調剤に関する考え方」として保険薬局の 約 7 割が“積極的に取り組んでいる”および“薬 効によっては取り組んでいる”と回答し, 一方“あ まり積極的には取り組んでいない”と回答した保 険薬局は $25.2 \%$ であった。取り組んでいない理由 として“近隣の医療機関が GE の使用に消極的” が最も多く，これまで GEが普及しない背景とさ れていた品質や効果, 安定供給体制, 情報提供体 制への薬剤師の不安等は少なくなりつつある。柴 田ら ${ }^{1)}$ も, 薬剤師は医師や患者より GE 推進に積 極的な立場にあることや GE 推進における問題は 情報不足や品質ではなく医薬分業体制のあり方や 診療報酬制度にあると認識していることを報告し ている。 また長井ら ${ }^{2)}$ の報告では, 調剤薬局を運 営する企業に所属する管理薬剂師の約 9 割が前向 きに GE 普及に取り組んでいると回答したとあ る. GE 推進への薬剤師による積極的関与や政府・ $\mathrm{GE}$ メーカーの取組み等により GEの数量シェア は年々増加し, “最近の調剤医療費 (電算処理分) の動向”によれば平成 24 年 7 月時点での GEの 数量シェアは $27.9 \%$ となっている (平成 24 年 12 月 6 日, http://www.mhlw.go.jp/topics/medias/c-med/ 2012/07/pdf/gaiyou.pdf)。こうした GEを取り巻く 状況について薬学生に対して問題意識を持たせる ことは重要であると考えられ, 上野 ${ }^{3)}$ は薬学に おける GE 教育を医薬品情報学や医療経済学のな かで講義として行い, その結果ほとんどの学生が GE の有効利用の重要性と薬剤師の果たすべき役 割が理解できたことを報告した。一方で学生に対 する教育効果が非常に大きいことから, 教員の GE に対する考え方や理解により GEに関する教 育においては大学間の違いが出る可能性があるこ とを懸念している。 そこで我々は, 薬学生に対し
て GE の特徴やその役割を理解させること並びに $\mathrm{GE}$ 教育プログラムを構築することを目的に平成 22 年度より「ジェネリック医薬品実習」を開始 した。これまで実習として GE教育を行ったとの 報告がみられなかったこと，また実物を用いた自 らの頭と手を用いる直接性が増した教材は有用で ある ${ }^{4)}$ との報告から，講義ではなく実習形式で行 うことを試みた。 今回, 平成 22 年度のプログラ 厶を翌年度改変・実施するとともに, GE の使用 経験及び実習による $\mathrm{GE}$ への意識変化について検 討した，あわせて，本実習プログラムの有用性に ついても検討したので報告する，なお，本報告は 九州保健福祉大学倫理審査委員会の承認を受けた ものである。

\section{方 法}

\section{1. 実習概要}

ジェネリック医薬品実習は，平成 23 年度実務 実習事前学習 II（6 年制 4 年次後期，10～11月） の一項目として実施した。実習指導は教員 2 名が 担当し, 158 名の学生を 2 クラスに分け, 1 日に 約 80 名を対象として 8 名程度の小グループで計 2 日間実施した。

表 1 にジェネリック医薬品実習内容を示す。最 初に実習前アンケート (10 分), 続いて GEの概 要および実習スケジュールの説明を行った（10 分). GE の概要説明の際, 「後発医薬品の安心使 用促進アクションプログラム」等について示し, そのなかで薬荗師がかかわっていることを伝え た. 実習の導入として実施した医薬品調査(1)では, プラバスタチン $\mathrm{Na}$ 塩錠 $10 \mathrm{mg}$ の先発品および GE1 種類を対象とし, 調査項目は, ジェネリック医薬品 採用マニュアルー富山県厚生部くすり政策課編 ${ }^{5}$ や福岡県ジェネリック医薬品採用マニュアル（福岡 県庁, 平成 20 年 1 月 http://www.pref.fukuoka.lg.jp/ uploaded/life/22/22635_14547826_misc.pdf）を参考 に, 品質, 製剤的特徵, 情報提供体制, 供給体制, 患者負担額とした (45 分). 医薬品調査(2)では, ランソプラゾール OD 錠 $15 \mathrm{mg}$, クラリスロマイ シンドライシロップ $10 \%$ およびケトプロフェン テープ $20 \mathrm{mg}$ について, それぞれ先発品および 
表 1 ジェネリック医薬品実習内容と概説

実習前アンケート（10 分)

背景調査 (GE の認知度, 医療用医薬品・GE の使用経験)

GE 使用上の重要項目，GE に対する知識および意識調査

$\mathrm{GE}$ の概要・実習スケジュール説明（10 分 $)$

GE の概要説明：GE とは?/GE と先発品の発売までの流れ／「後発医薬品の安心使用促進アクションプログラム」 について

○実習スケジュール説明：医薬品調査(1)・2)，スモールグループディスカッション

医薬品調査 1 (45 分)

○プラバスタチン $\mathrm{Na}$ 塩錠 $10 \mathrm{mg}$ (先発品：A, GE：B)について, 下記の医薬品評価項目を「医薬品評価表」にまとめた. 医薬品 (実物)，医薬品情報資料，インターネット等を活用し，調査を行った.

1. 品質

1）安定性：長期保存試験，光安定性，粉砕後安定性，無包装・カプセル開封後安定性の結果を確認

2) 生物学的同等性 : 先発品と GE の体内動態の同等性を確認

3）添加物：各医薬品の添加物の違いを確認

4）オレンジブック収載：品質再評価を確認

2. 製剤的特徵

1）プラバスタチン $\mathrm{Na}$ 塩錠：半錠にする際の調剂利便性を評価

3. 情報提供体制

1）IT・情報冊子：各医薬品メーカーのホームページや提供資料の充実度や利便性を評価

4. 供給体制

1）規格の品揃え：規格の品揃えの確認（例 医薬品(1)：5 mg・10 mg, 医薬品(2)：10 mg)

2）包装単位：包装単位の確認(例 医薬品(1)：10 錠シート $\times 10$ 枚 $/ 14$ 錠シート $\times 10$ 枚 / 瓶 500 錠, 医薬品(2)： 10 錠シート $\times 10$ 枚)

3）適応症：適応症の違いを確認

4）名称・外観：名称や外観の識別性等を確認

5. 患者負担額

1）プラバスタチン $\mathrm{Na}$ 塩錠：提示した薬局設定，服薬指導および情報提供の状況，処方条件「1日 1 回 1 錠/回 28 日分」における薬局空口での 1 回あたりの支払い額

医薬品調査(2)（120 分）

のランソプラゾール OD 錠 $15 \mathrm{mg}$ (先発品：C， GE：D・E・F），クラリスロマイシンドライシロップ 10\%（先発品： $\mathrm{G}, \mathrm{GE}: \mathrm{H} \cdot \mathrm{I} \cdot \mathrm{J}$ ), ケトプロフェンテープ $20 \mathrm{mg}$ (先発品 $: \mathrm{K}, \mathrm{GE}: \mathrm{L} \cdot \mathrm{M} \cdot \mathrm{N}$ ）について, 医薬品調査(1) と同様「医 薬品評価表」にまとめた。医薬品（実物），医薬品情報資料，インターネット等を活用し，調査を行った。

1. 品質：医薬品調査(1)同様

2. 製剂的特徵

1）ランソプラゾール OD 錠：におい，味，簡易懸濁法における崩壊懸濁性やチューブの通過性等を評価

2）クラリスロマイシンドライシロップ：におい，味，懸濁性や調剤利便性を評価

3）ケトプロフェンテープ：開封のしやすさ，剥がしやすさ，テープ剤のにおいや復元性等を評価

3. 情報提供体制：医薬品調査(1)同様

4. 供給体制：医薬品調査(1)同様

5. 患者負担額

1）ランソプラゾール OD 錠：提示した薬局設定，服薬指導および情報提供の状況，処方条件「1 日 1 回 1 錠/回 28 日分」に拈ける薬局空口での 1 回あたりの支払い額

2）クラリスロマイシンドライシロップ：提示した薬局設定，服薬指導および情報提供の状況，処方条件「1日 2 回 $0.5 \mathrm{~g} /$ 回 5 日分」における薬局空口での 1 回あたりの支払い額

3）ケトプロフェンテープ：提示した薬局設定，服薬指導および情報提供の状況，処方条件「28枚 1 日 1 回 貼付」における薬局空口での 1 回あたりの支払い額

スモールグループディスカッション・まとめ（60 分）

医薬品調査(2)について医薬品評価表を基に，患者・薬凨師の立場からそれぞれの医薬品の利点・欠点を「医薬品総 合評価表」にまとめた。

後発医薬品の使用状況調查結果概要（平成 23 年 10 月 21 日, http://www.mhlw.go.jp/bunya/iryou/kouhatu-iyaku/ dl/111205-01.pdf）の説明

実習後アンケート（10 分）

GE 使用上の重要項目，GE に対する知識および意識調査

実習に対する評価（実習内容項目別の有用度，GEへの主観的理解度，実習全体の満足度） 
$\mathrm{GE}$ 各 3 種類の組み合わせで医薬品調査(1) と同様 に調查させた（120 分). なお, プラバスタチン Na 塩錠 $10 \mathrm{mg}$, ランソプラゾール OD 錠 $15 \mathrm{mg}$, クラ リスロマイシンドライシロップ 10\%，ケトプロフェ ンテープ $20 \mathrm{mg}$ の先発品や GEは，これまでに報 告された先発品と GEの品質や使用感等の調査 ${ }^{6-11)}$ を基に選出した。 なお, 各医薬品の調査項目に対 する評価は，“優れている”，“どちらとも言えな い”，“優れていない”の3段階とした。 スモール グループディスカッションでは, その調査結果を 基に患者や薬剤師の立場を想定し, それぞれの医 薬品の利点・欠点を「医薬品総合評価表」（記載 形式は自由）にまとめ, 各医薬品を比較させた. さらに後発医薬品の使用状況調査結果概要（平成 23 年 10 月 21 日, http://www.mhlw.go.jp/bunya/ iryou/kouhatu-iyaku/d1/111205-01.pdf）を示し, GE の普及率等の現状を伝えた (60 分). 実習終了後, GE に対する知識・意識調查および実習に対する 評価を行うために，実習後アンケートを実施した (10 分).

\section{2. 実習アンケート}

実習前アンケートの調査項目は，対象者の背景 ( GE の認知度, 医療用医薬品・GEの使用経験 等), $\mathrm{GE}$ 使用上の重要項目, $\mathrm{GE}$ に対する知識お よび意識とし, 後発医薬品の使用状況調査結果概 要 (平成 23 年 10 月 21 日, http://www.mhlw.go.jp/ bunya/iryou/kouhatu-iyaku/dl/111205-01.pdf）を参考 に作成した。回答は 5 段階（「とてもそう思う」 〜「全くそう思わない」）で評価させた，実習後 アンケートでは前述の項目に加えて, 実習内容項 目別の有用度, GEへの主観的理解度および実習 全体の満足度を調査し，回答は 5 段階で回答させ た. 解析対象者はアンケート記入に不備のなかっ た 151 名とした。実習前後の比較については Wilcoxonの符号付き順位検定，実習による GEへ の主観的理解度を高めた項目についてはカテゴリ カル回帰分析を行った。

\section{結果}

GE について知っているかという質問に対し,
「よく知っている・知っている」と回答した学生 は 92.7\%（140/151名）であり，「どちらとも言 えない」が $6.0 \%$ （9/151 名），「知らない・全く 知らない」が 1.3\%（2/151名）であった（図 1-A）. GE どのように知ったかについて複数回答で尋ね たところ，最も多かったのは講義（69 件）であり， 次いでテレビ CM (65 件), 病院・薬局のポスター (18 件), インターネット (13 件), 新聞雑誌の記 事や広告 (12 件), 薬剤師による説明 (9 件), 医 師による説明（4 件）であった（図 1-B）.

表 2 に示す通り, 医療用医薬品を処方されたこ とがある学生は $84.8 \%$ （128/151 名）であり，そ のうち GE を勧められたことがある学生は $11.7 \%$ (15/128 名), ないおよびわからないと回答した学 生はそれぞれ $82.8 \%$ （106/128 名）および $5.5 \%$ （7/128 名）であった。また，GEを使用したこと のある学生が $14.1 \%$ (18/128 名), 使用したこと のない学生が $44.5 \%$ （57/128 名）であり, $41.4 \%$ （53/128 名）の学生がわからないと回答した.

図 2 に示すように，GEを使用するにあたって 重要なこととして, 実習前, 「効果（効き目）が あること」(87.4\%)，「空口で支払う薬代が安く

A.
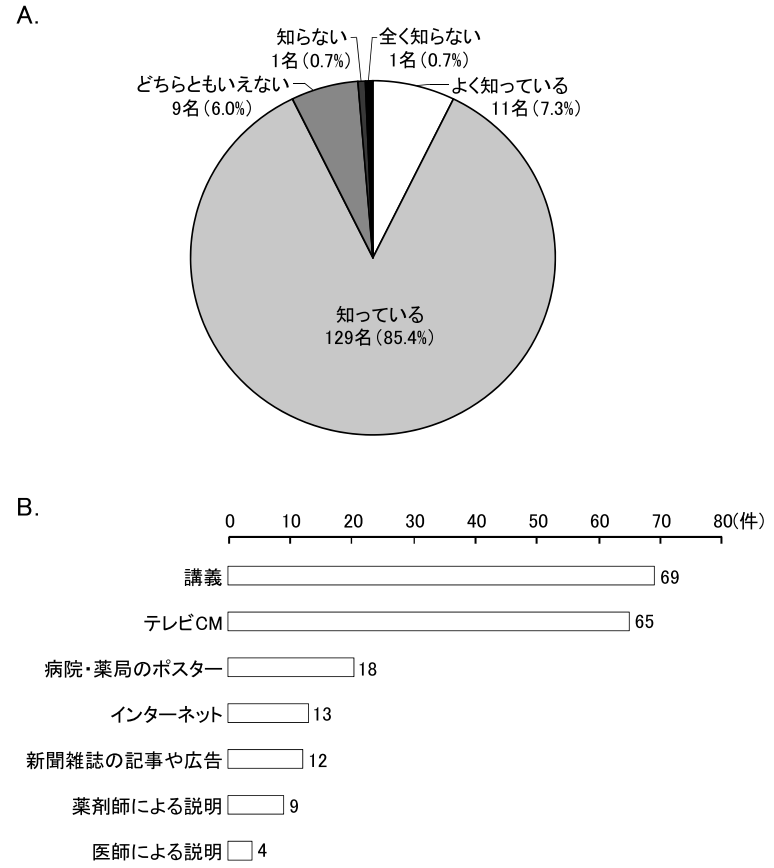

図1 GE について知っているか $(\mathrm{A})$ および $\mathrm{GE}$ をど のように知ったか $(\mathrm{B})$

B：よく知っている, 知っていると回答した学生 140 名対象 (複数回答) 
表 2 医薬品の使用経験

\begin{tabular}{|c|c|c|c|}
\hline & ある & ない & わからない \\
\hline 1）医療用医薬品を処方されたことはありますか？ & $84.8 \% \quad(128)$ & $9.9 \%(15)$ & $5.3 \%(8)$ \\
\hline $\begin{aligned} \text { 2) GE を勧められたことがありますか？ } \\
\text { 1）で“ある”と回答した者のみ }(\mathrm{n}=128)\end{aligned}$ & $11.7 \%(15)$ & $82.8 \%(106)$ & $5.5 \%(7)$ \\
\hline $\begin{array}{l}\text { 3）GE を使用したことがありますか？ } \\
\text { 1）で“ある”と回答した者のみ }(\mathrm{n}=128)\end{array}$ & $14.1 \%(18)$ & $44.5 \%(57)$ & $41.4 \%(53)$ \\
\hline
\end{tabular}

括弧内は人数とする

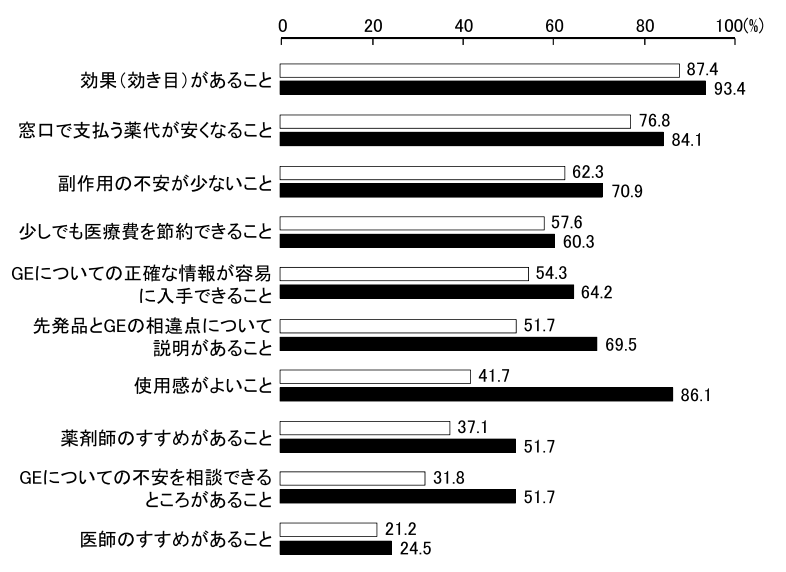

図 2 GE を使用するにあたって重要なこと $\square$ : 実習前 $\square$ : 実習後

なること」 $(76.8 \%)$,「副作用の不安が少ないこと」 （62.3\%）の選択率が高く，低かったのは「使用 感がよいこと」( $41.7 \%)$ および「薬剤師のすす めがあること」(37.1\%)，「GEについての不安 を相談できるところがあること」(31.8\%) およ び「医師のすすめがあること」(21.2\%) であった. 実習後 10 項目すべてにおいて選択率が増加し, 特に「使用感がよいこと」で 44.4\%の増加がみら れた，次いで「GEについての不安を相談できる ところがあること」で $19.9 \%$ ，「先発品と GEの 相違点について説明があること」で $17.8 \%$ ，「薬 剂師のすすめがあること」で $14.6 \%$ の増加がそれ ぞれみられた。なお，「医師のすすめがあること」 以外は, 実習後選択率は 5 割以上に到達していた。

表 3 に実習前後の GE に対する知識および意識 変化を示した。表 3 上段の GE に対する知識の変 化として先発品との比較に関する 6 項目のうち 4 項目において実習前後で有意差が認められた. $\lceil\mathrm{GE}$ は先発品と同じ効き目の薬である」では, 実習前「とてもそう思う・そう思う」と回答した 学生が $55.0 \%$ であり，実習後 $62.9 \%$ に増加した
$(P<0.01) .\lceil\mathrm{GE}$ は先発品と同じ成分の薬である」 に関しては「とてもそう思う・そう思う」と回答 した学生は実習前後で $82.1 \%$ から $69.5 \%$ 移行し たものの,「どちらとも言えない」の実習前後選 択率は $13.9 \%$ および $17.9 \%$ であり，変化がみられ なかった $(P=0.406)$.「GE は先発品と剂形, 色, 味，においが同じである」では「どちらとも言え ない」が実習により $43.0 \%$ から $17.9 \%$ に減少し， 「そう思わない・全くそう思わない」は $48.3 \%$ か ら $78.8 \%$ に増加した $(P<0.001)$.「 GE は先発品 よりも価格が安い」および「GEは先発品よりも 情報が少ない」において, 「とてもそう思う・そ う思う」と実習前 $97.4 \%$ および $60.3 \%$ が回答した が, 実習後それぞれ $44.4 \%$ おび $42.4 \%$ に減少し, 実習後「どちらとも言えない」がそれぞれ $2.0 \%$ から 49.0\%, 27.2\%から 37.1\%に増加した（ $P<0.01)$. 「GE は先発品よりも副作用が少ない」では，「ど ちらとも言えない」と回答した学生が $50.3 \%$ から $60.3 \%$ に移行したものの，「全くそう思わない・ そう思わない」の実習前後選択率は $42.4 \%$ およ゙ $36.4 \%$ であり, 変化が認められなかった（ $P=$ 0.314).

表 3 下段の GE に対する意識変化として，4 項 目のうち 3 項目について実習前後の意識に有意差 が認められた。「GEに興味がある」では「とて もそう思う・そう思う」と回答した学生が $75.5 \%$ であり, 実習後 $92.7 \%$ に増加した $(P<0.001)$.「患 者として GE を積極的に使用したい」については 実習前「とてもそう思う・そう思う」が 48.3\%,「ど ちらとも言えない」が $41.1 \%$ ああり，実習後はそ れぞれ 51.7\%，44.4\%に増加した $(P<0.05)$.「患 者に GEを针めたい」については「とてもそう思 う・そう思う」の実習前後選択率が $61.5 \%$ から $53.6 \%$ に減少し,「どちらとも言えない」は 
表 3 実習前後の GE に対する知識及び意識変化

\begin{tabular}{|c|c|c|c|c|c|c|c|c|c|c|c|c|}
\hline \multirow{2}{*}{\multicolumn{2}{|c|}{$\begin{array}{c}\text { GE に対する知識：先発品との比較 } \\
\text { (想定する回答) }\end{array}$}} & \multicolumn{5}{|c|}{ 実習前選択率（\%） } & \multicolumn{5}{|c|}{ 実習後選択率（\%） } & \multirow{2}{*}{$P$ 值 } \\
\hline & & 1 & 2 & 3 & 4 & 5 & 1 & 2 & 3 & 4 & 5 & \\
\hline 1) & $\begin{array}{l}\text { GE は先発品と同じ効き目の薬である.（生 } \\
\text { 物学的同等性を鑑みると同じ効き目である.） }\end{array}$ & 0.7 & 10.6 & 33.8 & 51.7 & 3.3 & 0.7 & 6.6 & 29.8 & 45.7 & 17.2 & 0.001 \\
\hline 2) & $\begin{array}{l}\text { GE は先発品と同じ成分の薬である.（有効 } \\
\text { 成分は同じであるが, 含有成分は異なる.） }\end{array}$ & 0 & 4.0 & 13.9 & 66.9 & 15.2 & 0.7 & 11.9 & 17.9 & 37.7 & 31.8 & 0.406 \\
\hline 3) & $\begin{array}{l}\text { GE は先発品と剂形, 色, 味, においが同じ } \\
\text { である. (同じではない.) }\end{array}$ & 3.3 & 45.0 & 43.0 & 8.6 & 0 & 20.5 & 58.3 & 17.9 & 1.3 & 2.0 & 0.000 \\
\hline 4) & $\begin{array}{l}\text { GE は先発品よりも価格が安い. } \\
\text { (さほど変わらない場合もある.) }\end{array}$ & 0 & 0.7 & 2.0 & 46.4 & 51.0 & 0.7 & 6.0 & 49.0 & 32.5 & 11.9 & 0.000 \\
\hline 5) & $\begin{array}{l}\text { GE は先発品よりも情報が少ない. } \\
\text { (一概にそうとは言えない.) }\end{array}$ & 0.7 & 11.9 & 27.2 & 49.0 & 11.3 & 2.0 & 18.5 & 37.1 & 35.8 & 6.6 & 0.001 \\
\hline 6) & $\begin{array}{l}\mathrm{GE} \text { は先発品よりも副作用が少ない. } \\
\text { (一概にそうとは言えない.) }\end{array}$ & 6.0 & 36.4 & 50.3 & 7.3 & 0 & 3.3 & 33.1 & 60.3 & 1.3 & 2.0 & 0.314 \\
\hline \multirow{2}{*}{\multicolumn{2}{|c|}{ GE に対する意識 }} & \multicolumn{5}{|c|}{ 実習前選択率（\%） } & \multicolumn{5}{|c|}{ 実習後選択率（\%） } & \\
\hline & & 1 & 2 & 3 & 4 & 5 & 1 & 2 & 3 & 4 & 5 & \\
\hline 1) & GE に興味がある。 & 0 & 1.3 & 23.2 & 70.2 & 5.3 & 0 & 0.7 & 6.6 & 80.1 & 12.6 & 0.000 \\
\hline 2) & 患者として GE を積極的に使用したい. & 1.3 & 9.3 & 41.1 & 43.0 & 5.3 & 0 & 4.0 & 44.4 & 42.4 & 9.3 & 0.025 \\
\hline 3) & 患者に GE を勧めたい. & 0 & 2.6 & 35.8 & 53.6 & 7.9 & 0 & 1.3 & 45.0 & 45.7 & 7.9 & 0.255 \\
\hline 4) & GE はかかりつけ薬局の推進につながる. & 0.7 & 11.9 & 39.1 & 43.0 & 5.3 & 2.0 & 4.6 & 27.8 & 52.3 & 13.2 & 0.000 \\
\hline
\end{tabular}

評価は，1：全くそう思わない，2：そう思わない，3：どちらとも言えない，4：そう思う，5：とてもそう思うの 5 段階とし，解析は Wilcoxonの符号付き順位検定を行った。

$35.8 \%$ から $45.0 \%$ に増加した $(P=0.255)$.「 GE はかかりつけ薬局の推進につながる」では，実習 前「とてもそう思う・そう思う」と回答した学生 は $48.3 \%$ であり，実習後は $65.5 \%$ に増加した $(P<0.001)$.

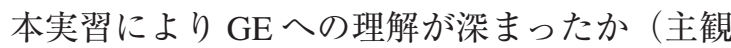
的理解度）に対し，「とても深まった」と回答し た学生は $33.1 \%$ であり，「深まった」が $64.2 \%$ と 最も多く，「どちらとも言えない」拈よび「深ま らなかった」がそれぞれ $1.3 \%$,「全く深まらなかっ た」と回答した学生はいなかった。

表 4 に実習内容項目別の有用度評価および GE の主観的理解度への関連性について示した，有用 度を “独立変数”, 主観的理解度を “従属変数” とし，それぞれ 5 段階で回答した項目をカテゴリ 分けし，回帰分析を行った。最も有用度評価が高 かったのは「製剂的特徵（におい・味, 懸濁性, フィ ルム剤の評価等)」であり, $98.7 \%$ の学生が「と ても役に立つ・役に立つ」と回答した．次いで「患 者負担額」,「生物学的同等性」,「安定性試験」, 「適 応症」,「規格の品揃え」,「名称・外観」,「添加物」, 「情報提供体制（ホームページ等）」，「包装単位」
の順であり, いずれも約 8 割以上の学生が「とて も役に立つ・役に立つ」と回答した（83.4 $92.1 \%)$ ．－方，「オレンジブック収載」は評価が 低く，「とても役に立つ・役に立つ」と回答した 学生は $68.2 \%$ であった. GEの主観的理解度への 関連性について,「生物学的同等性」,「名称・外 観」,「添加物」，「製剂的特徴」，「オレンジブック 収載」の順に正の相関が認められ（ $\beta=0.125$ $0.312, P<0.05)$, 「包装単位」については負の相 関が認められた $(\beta=-0.333, \quad P<0.001)$.

本実習の満足度については,「とても満足・満 足」と回答した学生が $92.7 \%$ でり,「どちらと も言えない」抒よび「不満足」が $6.0 \%$ および $1.3 \%$, 「とても不満足」と回答した学生はいなかった.

\section{考察}

我が国において GE 普及に向けた体制は徐々に 整ってきたものの，実際に数多く存在する $\mathrm{GE} の$ 中から採用医薬品として選定するためには, 品質 や情報提供体制，供給体制，経済面等，多くの事 項を検討することが求められる. ${ }^{5)}$ 本実習では $\mathrm{GE}$ 
表 4 実習内容項目別の有用度評価および GE の主観的理解度への関連性

\begin{tabular}{|c|c|c|c|c|c|c|c|}
\hline \multirow{2}{*}{ 実習内容項目 } & \multicolumn{5}{|c|}{ 有用度評価選択率 a）（\%） } & \multicolumn{2}{|c|}{ 理解度への関連性 b) } \\
\hline & 1 & 2 & 3 & 4 & 5 & $\beta$ & $P$ 值 \\
\hline 1）安定性試験 & 0 & 0 & 9.3 & 68.9 & 21.9 & -0.089 & 0.261 \\
\hline 2) 生物学的同等性 & 0 & 0 & 8.6 & 54.3 & 37.1 & 0.312 & 0.000 \\
\hline 3）添加物 & 0 & 0 & 10.6 & 51.0 & 38.4 & 0.206 & 0.008 \\
\hline 4）オレンジブック収載 & 0 & 1.3 & 30.5 & 54.3 & 13.9 & 0.125 & 0.025 \\
\hline $\begin{array}{l}\text { 5）製剤的特徵（におい・味，懸濁性， } \\
\text { フィルム剂の評価等） }\end{array}$ & 0 & 0 & 1.3 & 41.1 & 57.6 & 0.162 & 0.021 \\
\hline 6）情報提供体制（ホームページ等） & 0 & 0.7 & 11.9 & 53.0 & 34.4 & -0.072 & 0.334 \\
\hline 7）規格の品揃え & 0 & 0 & 9.9 & 58.9 & 31.1 & 0.056 & 0.507 \\
\hline 8）包装単位 & 0 & 0.7 & 15.9 & 57.6 & 25.8 & -0.333 & 0.000 \\
\hline 9）適応症 & 0 & 0 & 9.9 & 51.0 & 39.1 & 0.090 & 0.314 \\
\hline 10）名称 - 外観 & 0 & 1.3 & 8.6 & 55.6 & 34.4 & 0.290 & 0.000 \\
\hline 11）患者負担額 & 0 & 0 & 7.9 & 35.1 & 57.0 & 0.130 & 0.102 \\
\hline
\end{tabular}

a) 評価は, 1 : 全く役に立たない, 2 : 役に立たない, $3:$ どちらとも言えない, 4 : 役に立つ, $5:$ とても役に立つの 5 段階とした.

b) カテゴリカル回帰分析：従属変数を “GEへの主観的理解度”（5段階：全く深まらなかった〜とても深まった）とした. $\mathrm{R}^{2}=0.383$.

に変更したことにより使用感に変化が生じたとの 報告 ${ }^{11-14)}$ に鑑み，実際の医薬品の“製剂的特徵” を体感できる内容を導入した。

薬学生における GE の認知度では $90 \%$ 以上の 学生が「よく知っている・知っている」と回答し, GE を知った経緯は薬学部での講義に加え, テレ ビ CM が多いことが明らかとなった。患者の GE 情報入手方法には“テレビや新聞等のメディアか らが多い”とする報告があり, ${ }^{13)}$ 今回の調査成績 と一致した，特に GE を知った経緯として今回最 も多かった “講義”については，カリキュラム上 3 年次開講科目「調剂学」の医薬品情報 (90 分 $\times 1$ コマ）のなかで GE に関する生物学的同等性 の項目で取り扱われていることが確認できた。ほ とんどの学生が GE について「よく知っている・ 知っている」と回答していたものの, 講義のみの 知識であり本実習実施により“体験的”に GEに ついてょり理解を深めることが必要であったと考 えられる。

医薬品の使用経験について, 医療用医薬品を使 用したことのある学生は 8 割を占め, そのうち 「GEを勧められたことがある」あるいは「GEを 使用したことがある」と回答したのはそれぞれ 1 割程度であった．先発品から GEへの変更回数の 多い医薬品群は高血圧治療薬, 脂質異常症治療薬, 高尿酸血症治療薬や消化性潰瘍治療薬等が上位を
占め, また変更される患者の年代は 50～60 歳代 の中高年が多いと報告されている. ${ }^{14,15)}$ 今回の調 査対象者の大半が 20 歳代であったことや生活習 慣病等を含む慢性疾患への罹患率が一般に 20 歳 代では低いこと等が，GE使用経験者が少なかっ た主な理由ではないかと思われた。加えて, 薬学 生の 4 割が自身に処方された医薬品が GE かどう かを意識していないことが明らかとなった。最近 では「GEを信用できない, 先発品の方が良い」 として GEの変更を希望しない患者も存在する ${ }^{16)}$ との報告もあること，一方で医療機関における一 般名処方加算算定も始まっており, 薬剤師裁量で GE を選択することが求められるようになってい ることを考え合わせると, 今後 GEに対する問題 意識を持たせることが重要と思われる.

今回の我々の調査では“GE を使用するにあたっ て重要なこと”として, 実習前, 「効果があること」, 「空口で支払う薬代が安くなること」および「副作 用の不安が少ないこと」を選択した学生は 6 割以 上を占め,「使用感がよいこと」,「薬剤師のすすめ があること」，「医師のすすめがあること」，「GE についての不安を相談できるところがあること」 は 4 割程度あるいはそれ未満であり, 後発医薬品 の使用状況調查結果概要（平成 23 年 10 月 21 日, http://www.mhlw.go.jp/bunya/iryou/kouhatu-iyaku/ dl/111205-01.pdf 参照）と同様の結果が得られた. 
実習後，すべての項目において選択率が増加した ものの「医師のすすめがあること」ではわずかに 3\%程度しか伸びて扮らず，一方「使用感がよい こと」,「先発品と GE の相違点について説明があ ること」「薬剤師のすすめがあること」および「 $\mathrm{GE}$ についての不安を相談できるところがあること」 において大きく選択率が増加した．これらの項目 は GE に対する薬椷師の役割にかかわるものであ る. 薬剤師は患者に対し先発品との開発過程の違 いによる薬価差や外観, 使用感といった相違点を 説明したうえで，GE は国から承認されたもので あること, 先発品と同一成分, 同様の効果が得ら れることを説明することで，GEの使用促進に寄 与していくことが求められている．またこの役割 を果たすことにより，患者ひいては国民の GEに 対する不安を除くことが可能となる，本実習では 医薬品の製剤的特徵を評価することを主眼に置い ており, 学生が GE と先発品の使用感や相違点を 理解し, 薬剤師業務として GEについての不安を 相談するあるいは解消する役割を有すると捉えた ことにより，選択率が大きく増加したものと思わ れる.

GE に対する知識変化に関しては, 実習前,「GE は先発品と同じ効き目の薬である」については半 数以上が「とてもそう思う・そう思う」と回答し た．実習後は「とてもそう思う・そう思う」が有 意に増加し，生物学的同等性を鑑み効果は同じで あることを理解できたと考えられるものの，実習 後も「どちらとも言えない」と回答した学生が 3 割程度を占めていた，その理由は明確には言及で きないが，外用薬であるケトプロフェンテープに ついて生物学的同等性に関するデー夕がなかっ た，あるいは非臨床試験での同等性に関するデー 夕しか示されていなかったためである可能性があ る。このような局所皮膚適用製剂については,「局 所皮膚適用製片の後発医薬品のための生物学的同 等性試験ガイドライン」(薬食審査発第 1124004 号, 平成 18 年 11 月 24 日, 別紙 4）が示されて いることから，その内容を理解したうえで実習を 行うことが必要であったと思われる。 さらに，ケ トプロフェンテープに関しては，阿波ら ${ }^{17)}$ が先 発品および $\mathrm{GE}$ 間で全身移行性が大きく異なった
ことを報告しており, 生物学的同等性試験の結果 が示されていない外用薬等では文献等を検索する ことにより医薬品評価を行うことも必要ではない かと考えられた．実習前「GEは先発品と同じ成 分の薬である」については 8 割が「とてもそう思 う・そう思う」と回答したが, 実習後には 7 割に 減少し，「どちらとも言えない〜全くそう思わな い」が増加した。これは, 実習前に有効成分は同 じであることを理解していたものの, 実習後も“有 効成分”として同じであると考えた学生と添加物 が異なるため“含有成分”として同じではないと 考えた学生が存在したため回答にばらつきがみら れたものと考えられる.

GEに変更した患者から「薬代が思ったよりも 安くなかった」という意見が多く存在したとの報 告 ${ }^{13)}$ がある. 本実習では平成 22 年度調剂報酬点 数表に従って薬局空口で実際に患者が支払う金額 を算出させた。“後発医薬品調剤加算”および “後 発医薬品情報提供料” の加算・算定により「GE は先発品よりも価格が安い」において, 実習後「ど ちらとも言えない」と回答した学生が増加し, 先 発品でも GEでもさほど変わらないこともあり得 ることを理解したものと考えられる.

$\lceil\mathrm{GE}$ は先発品と剂形, 色, 味, においが同じ である」については, 実習後「全くそう思わない。 そう思わない」と選択した学生が増加しており, “製剂的特徵”の評価により各医薬品の特性の違 いを実際に体感したことにより，GEの外観や使 用感の違いについて理解したものと考えられる. また，「GEは先発品よりも情報が少ない」につ いて, GEメーカーの情報提供体制の整備が進ん できたことや発売後に不足情報を追加し, 充実し た医薬品情報の構築を目指す企業も存在すると言 われている. ${ }^{18)}$ ホームページの充実度等を評価す ることを通して, 必ずしも“GEの情報が少ない” というわけではないことを理解したのかもしれな い.「GEは先発品よりも副作用が少ない」につ いては，実習前後で有意な差はなく「どちらとも 言えない」との回答が多かった. どのような医薬 品にも副作用は起こり得るため, 先発品, GEに かかわらず一概にそうとは言えないことを実習前 から理解していたものと思われる。 
「患者として GE を積極的に使用したい」および 「患者に GE を勧めたい」では,いずれも実習後「ど ちらとも言えない」に収束し，一方で「GEに興 味がある」は「とてもそう思う・そう思う」に移 行していた．また「GEはかかりつけ薬局の推進 につながる」について，実習後「とてもそう思う・ そう思う」と回答した学生が有意に増加した，学 生の感想において GEを患者個人の状態や希望に 合わせて検討したいとの意見もみられ，患者ニー ズや使用感に基づく医薬品選択を意識しつつ, GE への興味が増したものと考えられる. 加えて患者 に適した医薬品を選択し，さらにそれを説明でき ることにより，患者との信頼関係が構築され，か かりつけ薬局の推進につながるとの意見もあった. 柴田ら ${ }^{1)}$ も薬㓱師は, 患者の GE に対するニーズ を聞き出すコミュニケーション能力や $\mathrm{GE}$ の情報 収集と評価から，患者に対応することが試されて いるとしている。しかしながら“GEを使用する にあたって重要なこと”として「薬剤師のすすめ があること」を考える患者は少ないとされ，薬郕 師は今後さらに積極的に患者に GEに関する情報 提供を行い，適正な GE 使用推進に寄与すべきも のと考えられる．実習前後の GEに対する知識の 変化から, 本実習により学生の $\mathrm{GE}$ への理解度が 高まったことが示され，薬剤師が果たすべき GE 使用推進という役割を理解したものと考えられる.

実習により GEへの主観的理解度が高まった項 目について，カテゴリカル回帰分析により検討し たところ， $\beta$ 值が高い順から “生物学的同等性試 験”, “名称・外観”, “添加物”, “製剂的特徵” お よび “オレンジブック収載”となり，有意な正の 相関が認められた。“生物学的同等性”は GEが 承認されるために必須の試験であり，それぞれの GE が独自の試験として同等性を担保していると されるものの, 各試験の標準製剂(通常, 先発品) の薬物動態パラメータは試験間で一定ではなく, また標準製剤の薬物動態パラメータが先発品のそ れと大きく異なる場合が散見されたとの報告もあ

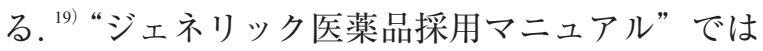
血中濃度推移が標準製剤と比べて“ほとんど変わ らない”，“基準の範囲内にある”，“大きなずれが ある”の3 段階で評価する ${ }^{5)}$ とあり，明確な同等
性の評価方法は記載されていない，そこで今回， 「グループごとの平均值の差を標準化」した効果 量の指標である Cohen's $d$ の算出 ${ }^{20)}$ を行い, 標準 製剤と GEの差がどの程度かを実感させたこと が, “生物学的同等性” の主観的理解度への関連 性が最も高かった要因と考えられる。しかしなが ら, 実習後「GE は先発品と同じ効き目の薬であ る」に対し 3 割の学生が「どちらとも言えない」 と回答しており, 客観的理解度としては不十分で あった．国から承認された医薬品であるにもかか わらず, 生物学的同等性について 3 段階評価や Cohen's $d$ の算出のみで評価することは誤解が生 じることも懸念されるため, 生物学的同等性試験 に関するガイドラインについて正しく理解した上 で実習に臨むことが必要である.

“添加物”に関しては $\mathrm{GE}$ へ変更後に添加物によ るアレルギーが発現した事例が報告されているこ と ${ }^{21)}$ や加藤ら ${ }^{22)}$ によって添加物が薬効や吸収に 影響を及ぼす可能性が示唆されていることに基づ き評価項目として本実習にも加えており, 先発品 と GE 間での “添加物”の違いによる影響を考え， $\mathrm{GE}$ の理解に促進的影響を及ほしたものと考えら れる。一方で，実習後「患者に GEを勧めたい」 に対し，「どちらとも言えない」と回答した学生が 増加した要因の 1 つとして, 添加物の影響を懸念 したことにより学生の意識変化が起こった可能性 も考えられるため, 各添加物の使用目的や安全性 についても検証する必要があったと思われる。こ れらのことから, 実習前の導入として 3 年次開講 科目「調剤学」の生物学的同等性に関する講義に おいて, 「後発医薬品の生物学的同等性試験ガイ ドライン」(薬食審査発 0229 第 10 号, 平成 24 年 2 月 29 日）について正しく理解させ, 加えてこれ に付随する添加物変更時の「含量が異なる経口固 形製剤の生物学的同等性試験ガイドライン」,「経 口固形製剂の処方変更の生物学的同等性試験ガイ ドライン」および「剤形が異なる製剤の追加のた めの生物学的同等性試験ガイドライン」について も提示し，GEの知識を高めたうえで実習を行う という“講義”と“実習”を連携した形式で実施 することを検討すべきであると考えられた。

“ジェネリック医薬品採用マニュアル”では, “名 
称・外観”について当該先発品やほかの採用品す べてとの類似性を評価する ${ }^{5)}$ とあり，また渡部ら ${ }^{23}$ は先発品から $\mathrm{GE} へ$ の変更, $\mathrm{GE}$ 同士の銘柄変更 に伴う外観類似性が調剂エラーや服薬ミスの引き 金となる危険性を懸念し，本項目を GE 採択基準 の 1 つとするべきとしている，本実習では，ほか の採用品との比較に PTP シートに記載される“薬 効表示” が医薬品の識別性に有用であるとする感 想もあったことから，本項目の評価が $\mathrm{GE} へ の$ 理 解につながったものと思われる.

先発品と GEの製剂的な特性を比較した報告に おいて，錠剤では半錠分割のしやすさ, ${ }^{24)} \mathrm{OD}$ 錠 では服用性（においや味），簡易懸濁法における 水への懸濁性・チューブ通過性, ${ }^{25,26)}$ ドライシロッ プでは服用性 (に打い, 味, 水への懸濁性), ${ }^{8-10)}$ テー プ剤では外袋の開封のしやすさ，フィルムの剥が し易さ，テープ剤のに扔い・復元性・伸縮性 ${ }^{11}$ といった“製剂的特徴”の項目が挙げられている. また同じ有効成分を持つ医薬品間で製剤的な特性 が異なり，使用感等への違いにつながるといった 報告も多くなされている。. ${ }^{6-14)}$ さらに従来服用して いた薬剤と同成分で色や形などが変わると服薬ア ドヒアランスが低下することが報告されているこ とからも, ${ }^{277}$ 各医薬品の特性の違いを知り, それ を患者に説明することや服用・使用後の医薬品適 正使用が行われたかどうかの評価を行うことは, 薬剤師の役割として重要であると考えられる。今 回, 有用度評価選択率も「とても役に立つ・役に 立つ」が $98.7 \%$ と高評価であり，“製剤的特徵” を実際に体感することにより GEに対する理解が 深まったものと思われる.

$\mathrm{GE}$ の品質を担保する溶出試験の結果が医療用 医薬品品質情報集（オレンジブック）として公表 され，“オレンジブック収載”は品質評価のうえ で重要なツールの 1 つであり, 本実習でも調査項 目に挙げた. しかしながら, 本項目は主観的理解 度への関連性があるとされたものの, その有用度 評価は低かった。「GE 採用にオレンジブックが 十分活用されていない」とする報告 ${ }^{28)}$ もあり，今 後薬学生に対し, オレンジブック総合版ホーム ページ（公開開始日：2002 年 9 月 9 日, http://www. jp-orangebook.gr.jp/）の利用法等について周知させ
ることが重要と考えられた.

一方で, “包装単位”について負の相関が認め られた理由については明確な回答を有していない が, 今回実務実習前の学生を対象としており, 包 装単位が薬剤師の業務の効率化や在庫管理にどの ようにかかわっているか十分な知識がなく, 予備 知識の少なかった学生ほど実習による有用性への 影響が大きかったという可能性がある.

実習により, 主観的理解度については $95 \%$ 以 上の学生が「とても媣まった・媣まった」と回答 し, また実習後, 先発品と GEの比較についての 理解度も概ね上昇した。また実習の満足度につい ては $90 \%$ 以上の学生が「とても満足・満足」と 回答しており, 高い評価が得られた。実習プログ ラム内容別の有用度に関して,「製剂的特徵」の 有用性が最も高く, 次いで「患者負担額」,「生物 学的同等性」であり, すべての項目において約 7 割以上の学生が「とても役に立つ・役に立つ」と 回答した. 以上の結果から, 本実習プログラムは GE の特徵や役割を薬学生に理解させるために有 用であったと考えられる，本実習を通して，医薬 品の効果, 副作用に加えて使用感・服用感につい ての評価等, 患者の視点に立った GEの適正使用 推進に貢献できる薬片師となることを期待した い.

\section{引用文献}

1）柴田ゆうか, 池田博昭, 佐和章弘, 塚本豊久, 野村 祐仁, 有田健一, 木平健治, 患者, 薬片師, 医師の 後発医薬品選択に影響する重要因子の抽出 - 後 発医薬品通知サービス実施地域と無実施地域の 調查一, 日本病院薬剤師会雑誌, 2011, 47, 450456.

2）長井紀章, 大野ひかる, 大和幹枝, 堀野智美, 北小路学, 伊藤吉將, 高田充隆, チェーン薬局に 所属する薬剤師の意識とジェネリック医薬品普 及に関する調査研究, 医療薬学, 2012, 38, 111-117.

3) 上野和行, 大学に打ける後発医薬品の教育, 月刊 薬事, 2010, 52, 1499-1503.

4）富重恵利紗, 河内明夫, 柴田由香里, 福森正郎, 園田純一郎, 鳴海恵子, 山田勝士, 本屋敏郎, 実務 実習事前学習における「薬局製剂実習」の実施 
とその評価, 医療薬学, 2010, 36, 817-825.

5）富山県厚生部くすり政策課, “ジェネリック医薬 品採用マニュアル”, 薬事日報社, 東京, 2006, pp.1-114.

6）矢野勝子, 五十嵐信智, 伊藤清美, 折井孝男, 倉田 なおみ, 飯田純一, 杉山 清, 簡易懸濁法におけ るプラバスタチン製剤の先発医薬品と後発医薬 品の比較検討, 医療薬学, 2008, 34, 699-704.

7）廣谷芳彦, 池田賢二, 瀬名波宏昌, 名徳倫明, ラン ソプラゾールロ腔内崩壊錠（ラソプラン ${ }^{\circledR} \mathrm{OD}$ 錠 $15 \mathrm{mg}$ およびタケプロン ${ }^{\circledR} \mathrm{OD}$ 錠15）の自動錠剤 分包機による調剂後の安定性に関する研究, Prog Med, 2010, 30, 1361-1368.

8）岡田祥恵, 嶽本絵理, 石坂敏彦, 内田享弘, クラリ スロマイシンドライシロップの先発品および後 発品の品質評価, 医療薬学, 2007, 33, 905-912.

9）山藤 満, 長谷川史朗, 金井 威, 佐藤吉壮, クラ リスロマイシンドライシロップの服用性に関す る検討, 日本薬剤師会雑誌, 2008, 60, 935-938.

10）大江利治, 高橋健太, 坂上麻美, 関沢祐一, 小田 雅子, 齊藤浩司, クラリスロマイシンドライシ ロップ剂服用時の苦味の評価, 日本病院薬剂師 会雑誌, 2008, 44, 605-607.

11）斉田翌美, 井上綾子, 石橋 久, 冨永宏治, 堀 里子, 三木晶子, 大谷壽一, 小野信昭, 澤田康文, 患者を対象としたケトプロフェンテープの使用 感に関する製剤間比較調査, 薬学雑誌, 2008, 128, 795-803.

12）泉 太郎, 堀 里子, 佐藤宏樹, 三木晶子, 澤田 康文, ツロブテロールテープ製剤の銘柄間切り 替えに伴う喘息症状, 副作用, 製剂使用感の変化 に関する実態調査, 薬学雑誌, 2012, 132, 617-627.

13）三浦郷子, 石田隆浩, 中神真寿美, 山岡恭子, 後発 医薬品に関するアンケート調査, 日本病院薬剤 師会雑誌, 2008, 44, 719-722.

14）吉岡秀明, 久津間信明, 藤原孝之, 藤本哲也, 阿部 康次, 代替調剂実施後の使用状況調查, 医療薬 学, 2008, 34, 977-982.

15）渡邊裕之, 中井由佳, 院外処方也んの後発医薬品 変更に関する調査（第 2 報）, 日本病院薬荗師会 雑誌, 2009, 45, 1483-1486.

16）井上 裕, 神谷享子, 尾高覀矢子, 則武和子, 金本 郁男, 東顕二郎, 森部久仁一, 山本恵司, 地域小規 模病院における糖尿病および高血圧患者への一 般名処方の現状, Prog Med, 2008, 28, 2013-2019.
17）阿波圭介, 佐藤宏樹, 堀 里子, 澤田康文, ケトプ ロフェンテープ先発・後発医薬品の全身移行性 のin vitro放出試験による予測, 薬学雑誌, 2012, 132, 135-144.

18）飯嶋久志, 小清水敏昌, 白神 誠, ジェネリック 医薬品における独自情報の客観的評価, 薬学雑 誌, 2007, 127, 541-545.

19）小玉菜央, 金本理沙, 叶 隆, 岡田裕子, 森本 かおり, 崔 吉道, 荻原环男, 医薬品添付文書中 の薬物動態パラメータの研究 (3) - ジェネリッ ク医薬品の生物学的同等性試験における薬物動 態パラメータの試験間および試験内変動の解析 -, 医療薬学, 2011, 37, 543-550.

20）小野寺孝義, 菱村 豊, “文科系学生のための新 統計学”, ナカニシヤ出版, 京都, 2005, pp.1-165.

21）冨重恵利紗, 河内明夫, 中目順子, 園田純一郎, 鳴海恵子, 佐藤圭創, 本屋敏郎, 宮崎県北部山間 地域住民の医療アクセスと医薬品適正使用状 況, 医療薬学, 2013, 39, 225-236.

22）加藤洋美, 吉井美智子, 小澤光一郎, 後発医薬品 の適正使用と医薬品添加物に関する研究, 薬学 雑誌, 2007, 127, 2035-2044.

23）渡部陽子, 佐藤弘希, 皆川淑哉, 月岡良太, 杉山 康浩, 岡山善郎, 異島 優, 渡邊博志, 門脇大介, 安楽 誠, 丸山 徹, 先発および後発医薬品の外 観類似性が服薬セイフテイマネジメントに及ぼ す影響, 医療薬学, 2012, 38, 18-24.

24）鈴木知則, 小杉満孝, 雪下君子, 南 武夫, 複数規 格を有する後発医薬品採用における半錠分割精 度の重要性, 日本病院薬剂師会雑誌, 2007, 43, 1121-1124.

25）倉田なおみ, タケプロン（ランソプラゾール） OD錠の利点一経管投与を中心にしてー, 薬局, 2005, 56, 2787-2790.

26）星野輝彦, 永田雅子, 徳永 誠, 小川 尚, 上釜 兼人, ファモチジン口腔内崩壊錠の先発品と後 発品の品質比較試験, 日本病院薬剂師会雑誌, 2007, 43, 391-394.

27) Kesselheim AS, Misono AS, Shrank WH, Greene JA, Doherty M, Avorn J, Choudhry NK, Variations in pill appearance of antiepileptic drugs and the risk of nonadherence, JAMA Internal Medicine, 2013, 173, 202-208.

28）井上 裕, 金本郁男, 佐藤眞治, 石井昌宏, 後発医 薬品の提供および管理に薬剤師が求めているも の, Prog Med, 2009, 29, 2319-2326. 